\title{
Ortega y la «Escuela de Madrid»
}

\section{ORTEGA: SU PRESENCIA EN LA CULTURA ESPAÑOLA}

Ortega, filósofo empeñado en la modernización de la cultura española «nació sobre una rotativa». «...Empieza a escribir públicamente en 1902 a los diecinueve años. Desde 1904 lo hace con continuidad. (En este mismo año leyó José su Tesis doctoral, «Los terrores del año mil»). ...Colabora con ellos - generación del 98- y con los hombres de su propia generación, en las revistas de la época - Vida nueva, Alma española, Faro-»'.

José Ortega y Gasset, creador de la única Escuela Filosófica española, nació en una familia de periodistas. José Ortega y Munilla, su padre, gustaba la prosa reposada, pero la urgencia del periodismo ganó la partida.

- «Mi abuelo, nos comenta Ortega Spottorno, tenía un gran sentido del periodismo. Creó los lunes del Imparcial, - una especie de extra del domingo-, en que escribieron Unamuno, Valle-Inclán, Baroja, etc... Quizás El País, y esto es una confidencia, saque el lunes un extra del domingo, dentro de poco tiempo» ${ }^{2}$.

Nicolás María Urgoiti, ingeniero de caminos, - ligado a la familia Ortega-, quiso recorrer todo el ciclo del papel: construir una papelera, fundar una editorial e imprimir periódicos, revistas y libros. A partir de esta idea, nació la Papelera, la editorial Espasa-Calpe y el diario «El Sol».

1. Julián MARías, Ortega. Circunstancia y vocación 2. «Revista de Occidente», Madrid 1973, págs. 13 y 14.

2. Agradecemos a D. José Ortega Spottorno la amabilidad con que respondió a nuestras preguntas sobre Ortega en la entrevista con él celebrada el 27-6-81. Posteriormente leyó nuestro trabajo y en carta de fecha 21-9-81 lo califica de valioso. Como se sabe El País sacó su primer númèro del lunes el 19-4-82. Lo que era una profecía se ha convertido en realidad antes de que nuestro escrito viera la luz. Por su parte Soledad Ortega nos escribió en estos términos: «He leído con sumo gusto su trabajo sobre mi padre - «Ortega y la Escuela de Madrid-. El trabajo, muy estimable, demuestra lo bien que han estudiado el tema». Soledad Ortega (Carta de fecha 18-111981). 
«Había un periódico, El Sol, cuya vista, cuando por azar encuentro un viejo número, me da gana de llorar. Porque este periódico fue posible en España, existió durante veinte años, de 1917 hasta que lo mataron en la guerra civil, y era una maravilla de composición, impresión, veracidad, decoro lingüístico y, sobre todo, colaboraciones. A consecuencia de una crisis interna, a comienzos de 1931, Ortega y algunos amigos suyos dejaron de escribir en El Sol y fundaron Crisol y después, Luz; pero creo que a pesar de todo, El Sol siguió más cerca de lo que era el pensamiento de Ortega, y éste volvió a escribir en El Sol sus últimos artículos políticos, a finales de 1933» ${ }^{3}$.

Ortega fue un verdadero generador y coordinador de la cultura de su tiempo: «Filosofía y poesía, sobre todo, adquirieron una calidad que la primera no había tenido nunca en España, la segunda desde el siglo XVII. De 1917 a 1936 se publicó diariamente en Madrid un periódico, El Sol, que era sin duda uno de los dos o tres mejores del mundo» ${ }^{4}$.

Muchos escritos de Ortega - como «La rebelión de las masas»- fueron publicạdos en este gran periódico que, a veces, cedía sus artículos a «La Nación» de Buenos Aires.

«Amando de Miguel ha sido, en efecto, el primero en hacer notar, desde el punto de vista de la sociología del intelectual y su poder, el gran poder que poseyó el intelectual individual José Ortega y Gasset, gracias a su talento, por supuesto; pero también al medio socio-cultural que, desde su infancia, le rodeó y a los poderosos instrumentos de industria cultural -el diario El Sol, la editorial Espasa-Calpe, por entonces la más avanzada de España, la Revista de Occidente y su propia editorial - que tuvo a su servicio. ...Entre tanto, la recién creada empresa del País, cuyo presidente fue desde su iniciación José Ortega Spottorno, y cuyos fundadores fueron todos, creo, orteguianos puros, esperaba su hora, es decir, su autorización. Llegada ésta, en los cinco años que han pasado y cumpliendo a su modo la profecia antes mencionada, ha llegado a ser el intelectual colectivo-empresarial de la España postfranquistà. El País procede pues, sin la menor duda, del orteguismo" 5 .

Estos esfuerzos editoriales los realizaba entonces la familia Ortega, según confiesa José Ortega Spottorno, en medio de una gran precariedad de recursos económicos: «Algunas veces, era preciso ir al periódico y cobrar el artículo para poder hacer la compra».

3. Julián MARÍAS, La vida intelectual en España durante la República / y 4. En «El País», 12 de julio de 1981.

4. Julián Marías, Los españoles. 2. «Revista de Occidente» (El Alción), 1972, pág. 55.

5. José Luis L. Aranguren, El País como empresa e intelectual colectivo. En El País, 7 de junio de 1981 . 
Ortega: «El temple» del escritor, «el plantearse el prójimo»

«Mi padre, dice Ortega Spottorno, trabajaba mucho. Cuando escribía, pensaba en el posible lector, intentaba dialogar con el lector. Decía que «había que plantearse el prójimo», esa era una especie de consigna. Mi padre tenía un gran entusiasmo por las cosas y por las personas».

José Ortega y Gasset necesitaba «estar en temple» para escribir e incluso para leer. Necesitaba adivinar la vibración y la vivencia de quien leyera sus páginas. Era preciso captar la onda, crear un campo de juego, establecer una especie de diálogo. «El lenguaje es por esencia diálogo, y todas las demás formas de hablar depotencian su eficacia. ...La palabra es un sacramento de muy delicada administración» ${ }^{6}$.

Quien escribe y quien lee están a veces en circunstancias tan díferentes que el diálogo se convierte en un doble monólogo. Algo similar puede ocurrir a la hora de leer un texto: «Estar en temple era muy importante para Ortega, nos asegura su hijo José. Mi padre recibía muchas cartas de sus múltiples admiradoras y de otras personas, pero no siempre las abría. Esperaba hasta estar en temple, estar en situación de comprender el estado de ánimo de quien las escribiera. A la muerte de Ortega, encontramos en sus bolsillos, entre sus papeles, algunas cartas que mi padre aún no había abierto a la espera de un momento de temple que al parecer, ya no llegó».

Reproduciremos algunos fragmentos de sus cartas, ya que nos parecen interesantes los aspectos de la obra orteguiana que en ellas se manifiestan.

A «Francisco Navarro Ledesma ?

Leipzig, 7 de marzo de 1905.

Querido Paco: Si usted supiera con cuánto gusto cojo ahora la pluma para escribirle, no me llamaría olvidadizo y todas esas otras cosas que me habrá usted llamado. Le aseguro que hasta hace dos o tres días (y hace diecisiete que salí de esa), no he vuelto a tomar posesión de mí mismo. He vivido doce o trece días en un estado inverosímil: Una pérdida absoluta de la memoria, de la voluntad, de la sensibilidad, del hacerme cargo, en fin de cuantos ingredientes agitados convenientemente producen esta butaca interior que se llama el yo». Pepe.

Ortega tenía un carácter abierto pero también cíclico, y a veces sufría depresiones. Ortega, comentarista de Freud, debía adivinar las luchas entre los distintos niveles del yo. Las circunstancias influían poderosamente en la dináу 13.

6. José Ortega y Gasset, La rebelión de las masas. Espasa-Calpe, Madrid 1969, págs. 10

7. José Ortega y Gasset, Epistolario, Colección el Arquero. «Revista de Occidente», 1974. 
mica de la personalidad. El yo, no es un yo puro, es un «yo y mi circunstancia, y si no salvo la circunstancia, recalca Ortega, no me salvo yo».

Hubo una vez un profesor en Salamanca que anhelaba ser reconocido por todo el mundo como un poeta. El poeta Unamuno envió un libro de poesía al «joven maestro» con esta dedicatoria: «A José Ortega y Gasset, su amigo, Miguel de Unamuno».

«Madrid, 22-III-1912.

Amigo Unamuno: Recibo su libro ${ }^{8}$. Muchas gracias. Es erróneo que yo no guste absolutamente de su poesía».

Unamuno deseaba conocer la opinión de Ortega sobre el valor de su poesía.

«Vitoria, 2-IX-1914.

Amigo don Miguel: De viaje me entero por el periódico del escopetazo de Bergamín. Si hay en ello lo más mínimo de atropello, injusticia o simplemente desdén u odiosidad a la «Kultura» le ruego que cuente incondicionalmente conmigo, con mi pluma y con mi mal genio. Suyo, Ortega».

En 1923 Ortega funda la Revista de Occidente, y ya en el mes de junio busca colaboraciones:

«Madrid, 6-VI-1923.

Querido don Miguel: Le agradecí sobre manera la cariñosa carta que me envió a la muerte de mi padre. Muchas veces, recuerdo que el comienzo de mi primer fervor por la obra de usted fue debido a las sugestiones que recibía de mi padre.

Quisiera ahora pedirle una cosa. De Francia me escriben que va usted a publicar en la revista de Metafísica un ensayo de Pascal. ¿Podría usted dar el texto español para una Revista mensual que ahora comienzo a publicar? La organización económica de la revista permite pagar muy decorosamente a sus colaboradores. Suyo affmo. José Ortega y Gasset».

Dicen algunos sofistas que la úlcera de duodeno es propia de gente inquieta, de gente que lleva en la sangre una misión que cumplir. Los apócrifos freudianos piensan que la úlcera de duodeno sólo la padecen los buenos escritores. Ortega padeció de duodeno sin llegar a la úlcera.

«La salud de mi padre, no se debe considerar excelente, dice José Ortega, nunca fue muy buena».

«Buenos Aires, sábado 28 de octubre 1940.

Querida Victoria ${ }^{9}$.

8. Se trata del libro Rosario de Sonetos líricos que Unamuno publicó en 1911.

9. Esta carta va dirigida a Victoria Ocampo, amiga de Ortega y mecenas de varios poetas, por ejemplo, Borges. 
...El jueves tuve que hacerme mi periódico sondaje de duodeno, el cual, a veces como ahora, me deja dos días con molestias grandes y continuas. Es el inconveniente de descender a lo profundo de sí mismo y hacerse buzo del propio abismo... Hoy, hubiera intentado verte..., pero he tenido que dedicar la tarde al puerto esperando a Pérez de Ayala. Un abrazo de Ortega».

Las mujeres ocuparon un espacio importante en la vida y hasta en la obra de Ortega: «Mi madre ayudó mucho a Ortega en sus dificultades, en sus depresiones... Oriega quería que las mujeres construyeran su propia cultura - la cultura masculina, nos dice José Ortega (hijo), está en decadencia-. Ortega quiso que María Zambrano fuese profesora ayudante en su cátedra. Ortega esperaba mucho de María Zambrano».

El autor de «La España invertebrada» esperaba quizás que María Zambrano abriera cauces a esta cultura femenina. Una misión semejante debió sugerir Ortega a Victoria, a Maruja Mallo, por ejemplo. Quizás motivase también esta cuestión a Rosa Chacel, y a un sinfín más de mujeres. Las mujeres salvarán la cultura igual que en otro tiempo salvaron las familias: «Las mujeres, y esto hay que decirlo, recalca Ortega (hijo), salvaron las familias en la emigración. Ellas se encontraban en mejores circunstancias a la hora de conseguir un trabajo, y además mantenían la moral alta en los momentos difíciles... Mi madre tradujo algunos libros para Espasa-Calpe con el fin de ganarse algún dinero»".

José Ortega y Gasset se levantaba temprano, tomaba café, y escribía en la cama, o en la mesa del comedor. Algunos días para poder comer era necesario retirar una multitud de libros que inundaban la mesa del comedor. Ortega se exigía mucho cuando escribía, pensaba en los posibles lectores, ponía un gran entusiasmo. El entusiasmo era su resorte secreto, la palanca de Arquímedes que movía el mundo cultural de su tiempo; «el entusiasmo es el motor de la ciencia». Ortega se entusiasmó con grandes proyectos, con grandes personas - Morente hablará de su gran amistad y su gran entusiasmo-. El entusiasmo fue su mejor amigo, le llevó a la cumbre de importantes empresas y a los valles de los desengaños.

«Ortega y Marañón, confiesa Aranguren, fueron muy amigos. Esa amistad se tradujo, luego, políticamente en la «Agrupación al servicio de la República». Porque en realidad era una agrupación de amigos: Marañón, Ortega, Pérez de Ayala, y luego, otros más jóvenes como García Valdecasas, muy orteguiano». Ortega fue senador republicano por León.

La República defraudó a Ortega: «No es eso, no es eso...». Ni una España, ni la otra, es necesario crear una tercera. «La política, según creía Ortega, puede significar dos cosas: arte de gobernar o arte de conseguir el gobierno y 
conservarlo. De otro modo hay un arte de legislar y un arte de imponer cierta legislación» ${ }^{10}$.

Igualmente hay dos patriotismos, creía Ortega, uno que mira al pasado intentando sintetizar lo bueno que en él hay. Otro mira, no a la tierra de los padres, sino a la tierra de los hijos, porque «el patriotismo verdadero es crítica de la tierra de los padres y construcción de la tierra de los hijos».

Según Mindán: «Unamuno se juega su destino vital con las ideas, pero Ortega sólo se juega su destino vital con la idea de modernizar España. Unamuno postula Hispanidad frente a Europeidad, Ortega quiere Europeidad dentro de la Hispanidad»"

Ortega heredó de la generación del 98 el gusto por viajar. Amaba a España, le encantaba conocer sus gentes y sus tierras, rincón a rincón. Le gustaba caminar a pie, viajar en mula, recorrer la piel de toro en automóvil. «El ser un intelectual con automóvil fue entonces un gran escándalo, nos comenta José Ortega Spottorno. A mi padre, continúa, le gustaba ir en coche hasta El Escorial - «pedernal gigantesco que espera el choque, la conmoción decisiva capaz de abrir las venas de fuego que surcan sus entrañas fortísimas. Hosco y silencioso aguarda el paisaje de granito, con su gran piedra lírica en medio, una generación digna de arrancarle la chispa espiritual» ${ }^{12}$. De vez en cuando, Ortega detenía el coche. Se bajaba. Caminaba un rato. Charlaba tranquilamente con su acompañante, Baroja, o Dantín Cereceda, o Paulino Garagorri... «Paulino fue hombre de confianza de mi padre. Creo que fue a Paulino Garagorri a quien le hizo las mayores confidencias. Quizás, algún día, Paulino publique estas confidencias...».

\section{La Residencia: Ortega y Juan Ramón Jiménez}

La Residencia de estudiantes, apodada "Colegio de los quince», se inauguró en 1910, el mismo año en que Ortega estrenara la cátedra de Metafísica. «Quince, pues, era el número de los primeros residentes, considerados como núcleo fundador por los que vinieron después y sobre todo por ellos mismos» ${ }^{13}$.

Ortega fue vocal del patronato de la Residencia. Asistió, pues, a su naci-

10. José Ortega y Gasset, Discursos políticos. Alianza Editorial, 1974, pág. 45.

11. Agradecemos al profesor D. Manuel Mindán la cordialidad con que nos facilitó importantes datos sobre Ortega y sus discípulos, a lo largo de la reciente entrevista que con él mantuvimos.

12. José Ortega y GASSET, Meditación del Escorial, en «El Espectador V-VI», pág. 220. «Revista de Occidente», 1972. («El Espectador», ocho volúmenes, recoge diversos artículos de Ortega, publicados de 1916-1934).

13. Alberto JiMENEZ, Historia de la Universidad española, Alianza Editorial, 1971, pág. 436. 
miento, a su crecimiento y a su muerte en los calores del verano del 36. En los primeros años de la Residencia y en diversas ocasiones posteriores, los estudiantes estuvieron orgullosos de la cercanía del «joven maestro».

«Juan Ramón Jiménez charlaba con mi padre muy frecuentemente. Eran buenos amigos, asegura José Ortega Spottorno. Mi padre estuvo muy relacionado con la Residencia de estudiantes».

En 1911, el rey visitó «la Colina de los chopos». Le recibieron, el presidente del Patronato de la misma, Sr. Menéndez Pidal, el presidente de la Junta de Ampliación de Estudios (J.A.E.), de reciente creación, Sr. Ramón y Cajal, y el Sr. Castillejo, secretario de la misma.

Onís en el discurso de apertura del curso de la Universidad de Oviedo (1912-13) decía: «Hay, en este momento, profesores aislados, pero aún no hay Universidad. ...Si algún hombre hubiera de dar yo el título de maestro... tendría el derecho de dárselo a Unamuno..., también a Menéndez Pidal y a Ortega. José Ortega y Gasset con más años delante y menos obra detrás, pero que ya no es, para los que hemos asistido a su cátedra y seguido el curso de sus explicaciones, tan sólo una esperanza, sino la capacidad más fuerte y original que en filosofía hemos tenido desde hace mucho tiempo y el creador de una nueva visión de los problemas nacionales. Puede decirse que nace en él el pensador cuyas ideas -originalmente concebidas y bellamente expresadas - radican en lo más central, tanto del problema de Europa como del problema de España».

Ortega solía pronunciar un discurso con ocasión de las fiestas de la Residencia.

A la «Resi» ofrendó Ortega su bellísimo libro «Meditaciones del Quijote» ${ }^{14}$ en 1914. Este ensayo supone el proyecto global de la obra orteguiana; aquí está ya parte del Ortega que llegaría a ser.

«En Meditaciones del Quijote intentó hacer un estudio del quijotismo... Don Quijote puede significar dos cosas muy distintas: Don Quijote es un libro y Don Quijote es un personaje de este libro... Estos ensayos investigan... el quijotismo del libro» ${ }^{15}$.

«...En torno mío abre sus hondos flancos el bosque. En mi mano está un libro: Don Quijote, una selva ideal.

He aquí otro caso de profundidad: la de un libro, la de este libro máximo. Don Quijote es el libro-escorzo por excelencia.

Ha habido una época de la vida española en que no se quería reconocer la

14. Este libro supuso para Ortega su consagración como ensayista de primera magnitud, su puesto de rango intelectual.

15. José ORTEGa y GASSET, Meditaciones del Quijote, en Obras Completas, vol. I, «Revista de Occidente», 1966, pág. 326. 
profundidad del Quijote. Esta época queda recogida en la historia con el nombre de Restauración. Durante ella llegó el corazón de España a dar el menor número de latidos por minuto» ${ }^{16}$.

«Meditaciones del Quijote» fue el primer ensayo publicado en la sección de ensayos de la Residencia. Juan Ramón Jiménez fue el director de esta sección. Se publicaron también trabajos de Ors, Zulueta, Pardo Bazán, Onís, Bergson, Cambó, Unamuno, Machado, etc...

Machado llegó a la Residencia de la mano de Juan Ramón. "Poesías completas» de Machado fue el único libro de poesía que publicó la Residencia: una gran excepción para un poeta excepcional de una excepcional Castilla - «luz central quintaesencia de las luces provinciales».

Unamuno era un buen residente, un verdadero maestro que tenía abierta su «escuela» de la mañana a la noche. Hombre austero y auténtico, daba un cierto tono y alentaba el pulso de la «Colina del alto chopo».

Por la cátedra de la. Residencia pasaron Einstein, Eddington, Keynes, Chesterton, M. Curie, Broglie, Valéry, Bergson, Aragón, Claudel, Marinetti, Mauriac y un largo etcétera.

«Este Cerro del viento, esta, Colina de los chopos», también acogió a Federico García Lorca: «Toda la poesía lunar de Juan Ramón está llena de mujeres que se asoman como locas a los balcones y dan a los muchachos que se acercan a ellas una bebida amarguísima de tuétano con cicuta» ${ }^{17}$.

Igualmente fueron residentes Guillén, Dalí, Buñuel, Celaya, etc. Dámaso Alonso, Pedro Salinas y Rafael Alberti acudían a visitarlos: «Las sobrias alcobas y los árboles de la Residencia han ayudado al crecimiento del espíritu liberal español, a la creación de sus mejores obras... Hija de la Institución Libre de Enseñanza, la Residencia de estudiantes vino siendo la casa de las más grandes inteligencias españolas. Baste señalar entre los nombres de sus huéspedes anteriores a García Lorca, los de Ramón Menéndez Pidal, Antonio Machado, Miguel de Unamuno, Ortega y Gasset, Américo Castro, etc.» ${ }^{18}$.

«La última vez que mi padre vio a Juan Ramón Jiménez fue en Lourdes, nos comenta José Ortega (hijo). Juan Ramón no era creyente, o al menos, no era practicante, pero le gustaba observar las procesiones, las manifestaciones religiosas, etc. Juan Ramón era maniático con las erratas, por causa de una errata, dejó de escribir en la Revista de Occidente: En una ocasión, examinando un número de la Revista, constató que había una $g$ mal puesta en un artículo suyo. Se enfadó muchísimo, porque, como saben, Juan Ramón le tenía ma-

16. José Ortega y GaSSET, Meditaciones del Quijote, pág. 337.

17. Federico García LorCA, Elegía a María Blanchard, «Revista de Occidente», 1963.

18. Rafael Alberti, En la Residencia de estudiantes, Apéndice lírico a la historia de la Universidad, de Alberto Jiménez. 
nía a esta letra. Por casualidad tenía allí el libro de Tagore, traducido por su esposa. Cuando le mostraron una errata en este libro, quedó demudado y no volvió a escribir más en la Revista».

«Hace ya bastantes años... recorría yo a lomos de mula la ruta del Cid, según ha sido reconstruida por nuestro maestro Menéndez Pidal, al hilo del viejo poema... No puedo ver estos mulitos romos, ...sin pensar que realizan casi el anhelo del gran Juan Ramón Jiménez cuando preparaba la edición ilustrada de Platero y yo - libro maravilloso, a la par sencillo y exquisito, humilde y estelar, que debía servir de premio infantil en todas las escuelas de España» ${ }^{19}$.

Ortega en las Instituciones de su tiempo

A Ortega le gustaba citar un refrán árabe que dice: «El hombre se parece más a su tiempo que a su padre».

«El hombre, afirmará el «joven maestro», más que naturaleza, tiene historia», y es dentro de la historia donde el hombre «llega a ser lo que es».

La Institución Libre de Enseñanza fue fundada por Francisco Giner de los Ríos, Nicolás Salmerón y Gumersindo de Azcárate, en el año 1876. Si bien Ortega no participó directamente en esta fundación, sí sentía una gran admiración por algunos de sus componentes, como es el caso de Gumersindo de Azcárate: «Don Gumersindo de Azcárate ha muerto. Al ausentarse tan venerable figura de entre nosotros parece entrar definitivamente en la historia... Azcárate parecía condensar sobre sí todas las alusiones, remembranzas y sentimientos que en nosotros aquel pasado levantaba... Le veíamos pasar emocionado como un Quijote vuelto a la cordura. Con él pasan las sombras de Castelar, Cánovas, Salmerón y Giner».

La Institución Libre de Enseñanza actuaba a través de la Junta de Ampliación de Estudios, de la Residencia, del Centro de Estudios Históricos, del Instituto Nacional de Ciencias Físico-naturales, dirigido por Ramón y Cajal, y del Instituto-Escuela.

«Los tres hermanos, nos dice José Ortega Spottorno, estudiamos en el Instituto-Escuela. La sección del Retiro es hoy el Instituto «Isabel la Católica» ${ }^{20}$.

Este Instituto-Escuela está ubicado en el «Cerrillo de San Blas», cima del Parnaso matritense. A esta zona llegó a llamársele «Barrio Griego» por la

19. José Ortega y GaSSET, Notas del vago estio, en el tomo V de «El Espectador», pág. 200.

20. F. JimÉnez de Gregorio, y otros, Crónica 79-80 del Instituto Isabel la Católica, Madrid 1981 . 
cantidad de intelectuales, pintores, artistas y poetas que en él vivieron, y que sobre él escribieron. Entre los primeros podríamos citar a Cervantes, Lope de Vega, Quevedo, Góngora; y entre los segundos, a Tirso de Molina, Quevedo, Juan Ramón Jiménez, etc.

«El Instituto-Escuela, prosigue José Ortega (hijo), ofrecía una enseñanza de calidad. Sus profesores estaban tan en contra de la enseñanza puramente memorística que mi hermano no había aprendido el alfabeto. Cuando mi padre comprobó que su hijo no sabía manejar el diccionario, se quejó a la dirección, diciendo que estaba bien el no hacer una enseñanza memorística pero que la cuestión del alfabeto ya caía en la exageración».

La junta de ampliación de estudios ${ }^{21}$ llevó a cabo importantísimas actividades para modernizar la cultura española y para preparar intelectuales y técnicos en todos los campos. La J.A.E. estaba en buenas manos: Presidente: Santiago Ramón y Cajal. Vocales: Menéndez Pidal, Menéndez y Pelayo, Altamira, Zaragüeta, María de Maeztu, Ortega y Gasset, etc...

«En estos tiempos, afirma Aranguren ${ }^{22}$, casi nadie leía libros extranjeros, pues era difícil importarlos y la gente no viajaba como ahora. Las ayudas o pensiones para estudiar en el extranjero dependían de la Junta de Ampliación de Estudios, y aquí la recomendación de Ortega era decisiva; porque Ortega ejercía el imperio cultural de esos años. Ortega lo polarizaba todo: Era el que mandaba en el país desde el punto de vista cultural. Así pues, muchos de los que iban a estudiar a Alemania eran orteguianos».

Ortega, y él mismo lo ha reconocido, tiene deudas con la filosofía alemana. Estuvo con el grupo de Marburgo, fue discípulo del neokantiano Cohen, y también recibió influencias de Dilthey, Scheler y otros. Se ha discutido si Ortega se adelantó o no al existencialismo. Nosotros vamos a ofrecer unas notas que Ortega publicó al respecto en su ensayo «Goethe desde dentro»: «Goethe se preocupa sin cesar de su vida, sencillamente porque la vida es preocupación de sí misma. En el admirable libro de Heidegger titulado «Ser y Tiempo», publicado en 1927, se llega a una definición de la vida próxima a ésta. No podría yo decir cuál es la proximidad entre la filosofía de Heidegger y aquella que ha inspirado siempre mis escritos, entre otras cosas, porque la obra de Heidegger no está aún concluida, ni, por otra parte, mis pensamientos adecuadamente desarrollados en forma impresa; pero necesito declarar que tengo con este autor una deuda muy escasa. Apenas hay uno o dos conceptos importantes de Heidegger que no preexistan, a veces con una anterioridad de trece años, en

21. Francisco LAPORTA, y OTROS, Informe sobre la Institución Libre de Enseñanza y la J.A.E., en «Historia $16 », \mathrm{n} .{ }^{\circ} 49$.

22. Agradecemos al profesor Aranguren, «discípulo de Ortega en su juventud», que contestara a nuestras preguntas con espontaneidad y cordialidad. 
mis libros. Por ejemplo: La idea de la vida como inquietud, preocupación e inseguridad, y la cultura como seguridad y preocupación por la seguridad, se halla literalmente en mi primera obra, Meditaciones del Quijote, publicada en $¡ 1914$ ! — capítulo titulado «Cultura-seguridad», páginas 116-117 ${ }^{23}$.

El hombre es autor, actor y espectador de su propia existencia, decía alguna vez Ortega. El profesor Mindán encuentra en esta frase orteguiana sabores existencialistas.

Continúa Ortega analizando los conceptos que él considera preexistentes a la obra de Heidegger: "La vida como enfronte del yo y su circunstancia (c. pág. 43), como «diálogo dinámico entre el individuo y el mundo» en hartos lugares. La estructura de la vida como futurición es el más insistente leitmotiv de mis escritos, inspirado por cierto en cuestiones muy remotas del problema vital al que yo le aplico - suscitadas por la lógica de Cohen-. Asimismo: «En suma, la reabsorción de la circunstancia en el destino concreto del hombre», página 43, y la teoría del «fondo insobornable» que luego he llamado «yo auténtico». Hasta la interpretación de la verdad como aletheia, en el sentido etimológico de «descubrimiento, desvelación, quitar un velo o cubridor», se halla en la página 80 , con el agravante de que en este libro aparece ya el conocimiento bajo el nombre - itan hiperactual! - de «luz» y «claridad» como imperativo y misión inclusos «en la raíz de la constitución del hombre» ${ }^{24}$.

Dice Aranguren que «cuando salió» «Ser y Tiempo» de Heidegger, el único ejemplar que había en la Universidad, estaba en la cátedra de Ortega. Era casi imposible leerlo, porque siempre lo estaba leyendo alguien. Ortega afirmaba que aquello lo había dicho él antes, pero la verdad es que exageraba un tanto, quizás por ese prurito de la originalidad que tenía».

Ortega sabe que está influenciado por la filosofía germánica, pero lamenta que no se le reconozca su originalidad, porque hay muchas personas que distraídas por el bello plumaje de su prosa, «resbalan sobre sus pensamientos». Aún otra demostración: «Por ejemplo: «vivir es, de cierto, tratar con el mundo, dirigirse a él, actuar en él, ocuparse de él». ¿De quién es esto? ¿De Heidegger, en 1927, o publicado por mí con fecha de diciembre de 1924 en «La Nación» de Buenos Aires, y luego en el tomo VII de «El Espectador» («El origen deportivo del Estado»)? vital» 25 .

...El tema de nuestro tiempo consiste en reducir la razón pura a la «razón

Una de las actividades más fructíferas de la J.A.E. fue la concesión de pensiones para el extranjero y para España. Es increíble la labor realizada en

23. José OrTega y Gasset, Triptico-Mirabeau o el politico, Kant-Goethe, Espasa-Calpe, 1972, pág. 139.

24. José Ortega y Gasset, Tríptico, pág. 140.

25. José Ortega y GasSET, Tríptico, págs. 140-141. 
este sentido con unos medios económicos modestos. La calidad de los pensionados fue extraordinaria. Se concedieron unas mil setecientas pensiones para el extranjero, un $20 \%$ de las solicitadas. Las materias más becadas fueron: Pedagogía 19\%, Medicina 18\%, Ciencias Físico-naturales 17\%, Historia del Arte $10 \%$, Derecho $10 \%$, Filosofía y Poesía $9 \%$.

A continuación anotaremos algunos nombres de los pensionados en cada especialidad; así podrá comprenderse más adecuadamente la magnitud de la obra científica de la junta de ampliación de estudios: Medicina: Severo Ochoa, Jiménez Díaz, Laín Entralgo, Rof Carballo, Novoa Santos, López Ibor, etc.

Pedagogía: Cossío, Luzuriaga, Castillejo, Rosa Sensat, Roselló, etc.

Física y Química: Moles, Blas Cabrera, Casares Gil, Terradas, Hernández Pacheco, Royo Gómez, Cuatrecasas, etc.

Historia, Arte: Gómez Moreno, Hinojosa, Bosch Gimpera, SánchezAlbornoz, Pérez Bustamante, Esteve, Salazar, Zabaleta, Sáinz de la Maza, etc.

Derecho: Azaña, Wenceslao Roces, Prieto Castro, Saldaña, Jiménez de Asúa, Fernando M. ${ }^{\text {a }}$ Castiella, Legaz Lacambra, etc.

Filosofía, Poesía, Lingüística: Ortega y Gasset, Morente, Zubiri, Besteiro, Bonilla San Martín, Antonio Machado, Alberti, Pérez de Ayala, Navarro Tomás, Juan Corominas, etc.

La J.A.E. concedió también seiscientas ayudas aproximadamente para realizar estudios dentro del país. Entre los becados están: Juan Zaragüeta, Pedro Salinas, Valbuena Prat, Onís, Menéndez Pidal, Joaquín Xirau, etc.

La junta de ampliación de estudios fue disuelta en 1937 y sus locales pasaron al Consejo Superior de Investigaciones Científicas, creado en 1939.

En 1913 nace la «Liga para la educación política española». Estaba formada por un buen número de intelectuales liberales, que sin estar demasiado ligados a la Institución Libre de Enseñanza, no estaban lejos de sus principios pedagógicos. No olvidemos que D. Manuel García Morente dedica su libro «La Filosofía de Kant» «A la memoria de D. Francisco Giner de los Ríos». Los principales componentes de la Liga fueron: «Ortega, Azcárate, Azaña, Fernando de los Ríos, Américo Castro, Morente, etc.».

Con la Dictadura de Primo de Rivera, las instituciones liberales sufren un revés. La propia Universidad acusa esta violencia, renunciando a sus cátedras Ortega, Fernando de los Ríos, García Valdecasas, etc. Se clausura el Ateneo.

En el «Prospecto» de la Liga para la educación política española, Ortega define así esta Institución: «Reunidos en una agrupación de enérgica solidaridad que lleva este nombre, pensamos unos cuantos españoles emprender una serie de trabajos destinados a investigar la realidad de la vida patria, a propo- 
ner soluciones eficaces y minuciosamente tratadas para los problemas añejos de nuestra historia, a defender por medio de una crítica atenta y sin compromisos, cuanto va surgiendo en nuestro país con caracteres de aspirante vitalidad contra las asechanzas que mueven en nuestro derredor todas las cosas muertas o moribundas»" ${ }^{26}$.

Es posible, admite Ortega, que el pueblo español parezca una cierta inercia secular, pero el fondo del problema está en la inexistencia de minorías rectoras, que colaboren a la "organización de España»: «Salvo casos insólitos en tiempo y espacio, las masas españolas no se hallan políticamente movilizadas. Dicen que esto obedece a una peculiar inercia del pueblo español. Nosotros, sin negar esta razón, declaramos no entenderla. No entendemos que pueda hablarse de masas inertes donde falta el intento repetido de minorías directoras para sacarlas de su indolencia»" 27.

Las teorías de Ortega sobre las masas y las minorías han padecido graves y pertinaces malentendidos. Es falso que Ortega no dé ninguna misión a la masa popular: «Es completamente erróneo suponer que el entusiasmo de las masas depende del valer de los hombres directores. La verdad es estrictamente lo contrario: El valor social de los hombres directores depende de la capacidad de entusiasmo que posea la masa» ${ }^{28}$.

Minoría directora no es lo mismo que élite oligárquica. La minoría directora no está compuesta por las élites económicas ni por las élites políticas que luchan por conseguir el gobierno y conservarlo. Las minorías rectoras se nutren con los mejores, aunque estos procedan de familias humildes. Para Ortega los mejores son los más preparados, los que se esfuerzan en superar su competencia. El carácter de una nación se puede definir por la ecuación entre sus masas y sus minorías.

La forma óptima de gobierno sería aquella que «hiciera posibles estas dos cosas: democracia y España. Por entenderlo de otro modo han vivido los republicanos españoles en un Aventino sempiterno, haciendo de una posada su casa solariega y negándose a colaborar positivamente en lo que es para nosotros sustancial: la organización española» ${ }^{29}$,

Ortega, el joven maestro, define así la educación: «A esta acción de sacar una cosa de otra, de convertir una cosa menos buena en otra mejor, llamaban los latinos eductio, educatio. Por la educación obtenemos de un individuo im-

26. José OrTEga y GASSET, Prospecto de la Liga para la educación política Española, Obras Completas, vol. I, pág. 300.

27. José OrTEGa y GASSET, «Obras Completas», vol. I, pág. 301.

28. José Ortega y GaSSET, «La España invertebrada», Ed. Espasa-Calpe (Austral), 1980, pág. 97.

29. José Ortega y Gasset, «Obras Completas», vol. I, pág. 306. 
perfecto un hombre cuyo pecho resplandece en irradiaciones virtuosas. Nativamente aquel individuo no era virtuoso, ni sabio, ni enérgico; mas ante los ojos de su maestro flotaba la imagen vigorosa de un tipo superior de humana criatura, y empleando la técnica pedagógica ha conseguido inyectar este hombre ideal en el aparato nervioso de aquel hombre de carne» ${ }^{30}$.

Ortega hace una llamada a la juventud, le advierte de los peligros de la inactividad y el pasotismo: «A los jóvenes, sobre todo, quesiéramos incitar. Las nuevas generaciones han aprendido en la justa desconfianza, en el hábito insustituible de la crítica más acerba, pretexto para la inacción. Han abandonado la política. ¿Esto es bueno? Creemos que no, ni para la nación ni para ellos, que no conseguirán dar a su vida intelectual la máxima intensidad $"$ ".

\section{Revista de Occidente}

«...(He aquí) la misión que cumplió la Revista, casi heroicamente, de 1923 a 1936: la incorporación al ámbito hispánico de lo que entonces constituía la cultura, circunscrita al mundo occidental». (Soledad Ortega).

La Revista de Occidente, fundada por Ortega en 1923, fue el principal instrumento y el notario, a la vez, de la modernización de la cultura española.

«Desde 1923 hasta la misma fecha (1936) apareció mensualmente la $R \boldsymbol{e}$ vista de Occidente, dirigida por Ortega, cuya calidad acaso era igualada, pero no superada, por ninguna otra de ningún país. España se puso «al día» en su información de la cultura extranjera, hasta tal punto que son muchos los libros capitales del primer tercio de nuestro siglo que han sido traducidos al español mucho antes que a las demás lenguas occidentales» ${ }^{32}$.

Aranguren hace la valoración siguiente: «Durante los años veinte, la influencia de la Revista de Occidente fue total en toda la vida cultural española, no sólo en la vida filosófica, sino también en la cultura en general».

El número uno de la Revista de Occidente salió en junio de 1923. El director, D. José Ortega y Gasset; el precio: 3,50 ptas. Colaboraron Pío Baroja, Simmel, Schulten, Ortega, Gerardo Diego, Fernando Vela (excelente amigo, y colaborador infatigable de Ortega), y otros.

30. José Ortega y GaSSET, «Obras Completas», pág. 508.

31. José OrTEga y GASSET, «Obras Completas», pág. 307.

32. Julián Marías, Los españoles 2. pág. 55. Uno de esos traductores L. Cilleruelo, que tradujo E. PrZywara, San Agustín. «Revista de Occidente» 1949; nos dice en conversaciones personales que prácticamente lo más interesante de la cultura española desde 1927 se mueve en torno a Ortega y que todo el mundo, en cierta manera, se consideraba entonces orteguiano, incluido él mismo, fuera de la mentalidad que fuera. 
A modo de editorial se publicó una nota en la que se hacian constar los propósitos de la Revista:

«Propósitos:

Los propósitos de la Revista de Occidente son bastante sencillos.... En la razón presente adquiere mayor urgencia este afán de conocer «por dónde va el mundo», pues surgen dondequiera los síntomas de una profunda formación de las ideas, en los sentimientos, en las maneras, en las instituciones... Procurará esta Revista ir presentando a sus lectores el panorama esencial de la vida europea y americana»" ${ }^{3 .}$.

El n. ${ }^{\circ} 2$ de la Revista de Occidente, fue inaugurado por Juan Ramón Jiménez con un bellísimo trabajo: "Colina del alto chopo». Juan Ramón explica poéticamente cómo era el Madrid de entonces. Describe «Los altos del hipódromo, los rebaños de Madrid», «bruma y oro en el Retiro». «Sólo la creación vence a la creación».

En este $n .^{\circ} 2$ escribe García Morente: «La nueva filosofía de la historia», comentario a La decadencia de Occidente que se comenzó a publicar en Madrid, Calpe, 1923.

En el $n .^{\circ}$ 3, colabora D. Antonio Machado. Y así una larga fila de hombres del 98 , del 27, junto a importantes nombres de la cultura extranjera.

Dice Aranguren que a la Revista de Occidente le salió un rival justo con el advenimiento de la República: «Se trata de la revista Cruz y Raya, una publicación más de izquierdas y, a la vez, más católica. Bergamín era el director, y Bergamín, a su modo, es católico. Cruz y Raya restó alguna influencia a la $R e-$ vista de Occidente. Como saben, Ortega fue diputado republicano, pero se separó de la República un tanto desencantado».

«En 1933 se agregó Cruz y Raya, también de nivel muy alto; ambas, prodigiosamente escritas» ${ }^{34}$.

La Revista de Occidente, además de realizar una importante labor filosófica, cuenta con un brillante historial científico y literario. La mayor parte de la poesía del 27 vio la luz en sus páginas.

José Ortega Spottorno nos lo cuenta así: «La Revista de Occidente y su editorial aportaron las ideas de nuestro siglo. Creó una escuela de traductores: Morente, Gaos, Zubiri, Ortega, etc... Acercó a España la obra de importantes pensadores europeos».

En ¡1929!, la editorial de la Revista publicó las «Investigaciones Lógicas» de Husserl, un libro tremendo que inauguró la potente filosofía del si-

33. Propósitos, en el número 1 de «Revista de Occidente», 1923, julio, págs. 1 y ss.

34. Julián MARíAS, Vida intelectual en España durante la República, en «El País», 12 de julio de 1981. 
glo XX. La traducción fue hecha por Morente y Gaos. Este último solía explicar en sus clases la fenomenología de Husserl.

La Revista abrió una puerta a la cultura española y otra a la europea. Entre ambas se originó una corriente que nos despertó de un largo letargo y nos devolvió el entusiasmo por la cultura.

En 1963 se reeditó la Revista, en sus primeros números colaboraron (n. ${ }^{\circ}$ 2) Menéndez Pidal, Julián Marías, J-P. Richard, Eugéne Jonesco, Miguel Delibes, Maravall, Urgoiti, J. L. Sampedro, J. Rof Carballo, G. de Valdeavellano, Aranguren, Juan Benet, Fernando Vela.

Director: José Ortega Spottorno. Secretario de redacción: Paulino Garagorri. Consejo asesor: Fernando Chueca Goitia, Luis Díez del Corral, Enrique Lafuente Ferrari, Pedro Laín, Rafael Lapesa, y algunos de los colaboradores arriba citados.

El joven Vicente Aleixandre, entonces, escribía así: «Era en los ar̃os en que yo me había adentrado en la prosa de Azorín, Valle-Inclán, Unamuno, Ortega... La novela realista del siglo XIX, la pléyade de prosistas del 98, el teatro del XIX (estaba en verso)...

Rubén Darío fue el primer poeta al que yo me acerqué. Otro muchacho de mi edad (Dámaso Alonso: en alguna página distinta lo he contado) fue quien puso en mis manos los poemas» ${ }^{35}$.

La Revista de Occidente renace por segunda vez (1980) en las manos de Soledad Ortega como director, Vicente Verdú, secretario de redacción. Arango, Violeta Demonte, Emilio Lamo de Espinosa, Antonio Lara, Ana Puértolas, están en el Consejo de redacción. Aranguren, Rubert de Ventós y nuevos valores ponen sus firmas después de la viñeta de la antigua amiga Maruja Mallo.

La reaparición de la Revista de Occidente, dice Soledad Ortega en la «Presentación», responde a un hondo e íntimo impulso de quien hoy escribe estas líneas... Significa también el decidido propósito de contribuir a mantener una corriente de circulación entre las culturas ibéricas y las latinoamercicanas... Cuidará... establecer una sección informativa de crítica y notas, seria, objetiva y al día... Lo que urge ahora es contribuir a mantener la comunicación interdisciplinaria» ${ }^{36}$.

Después de desear éxito a la Revista en la nueva etapa que hace un año emprøndió, deseamos hacer un comentario sobre la editorial de la Revista de

35. Vicente AleIXANDRE, Los encuentros. Rubén Darío en un pueblo castellano, en «Revista de Occidente», 1963, pág. 293.

36. Soledad Ortega, Presentación, «Revista de Occidente» n. ${ }^{\circ} 1,1980$. 
Occidente. Comentaremos brevemente un libro de Dilthey traducido por Julián Marías y publicado en esta editorial en 1944.

La obra de Dilthey es imprescindible para comprender bien la filosofía de Ortega. En "Teoría de las concepciones del mundo» están las bases del vitalismo, y de la historicidad, con importantes repercusiones en corrientes actuales de pensamiento y concretamente en Ortega.

Según Ortega, «Dilthey descubre la idea de la vida»: «La última raíz de la visión del mundo es la vida. Esparcida sobre la tierra en innumerables vidas individuales, vividas de nuevo en cada individuo y conservada... en la resonancia del recuerdo; más comprensible, por otra parte, en toda su hondura de inteligencia e interpretación, tal como se ha objetivado en sus exteriorizaciones, que en toda percatación y aprehensión del propio vivir, la vida nos está presente en nuestro saber en innumerables formas, y muestra, sin embargo en todas partes los mismos rasgos comunes» ${ }^{37}$.

Estas líneas de Dilthey las comenta Julián Marías de la forma siguiente: «Ahora bien, todo hombre histórico tiene lo que llama Dilthey una Weltanschauung, una idea o concepción del mundo, que no es primariamente una construcción mental. La filosofía, la religión, el arte, la ciencia, las convicciones políticas, jurídicas o sociales, son elementos, ingredientes y manifestaciones de la idea de mundo; pero ésta, como tal, es algo previo y anterior, que tiene como supuesto general la realidad de la vida misma: La última raíz de la concepción del mundo - dice Dilthey- es la vida» ${ }^{38}$.

Vivencia y comprensión es el dúo del que nacerá el acorde de la concepción del mundo.

\section{LA ESCUELA DE MADRID}

«Alrededor de Ortega se ha formado un núcleo, cada día más creciente, de jóvenes en cuyo espíritu se entrelazan dos anhelos: poseer la cultura europea y realizar la salvación de España» (Onís).

El primero que denominó a este núcleo «Escuela de Madrid» fue Julián Marías, y quien contribuyó decisivamente a la difusión de este nombre, Ferrater Mora, incluyéndolo en su diccionario de Filosofía.

En 1910 Ortega es nombrado catedrático de Metafísica de la Universidad de Madrid. Se podría tomar esta fecha como el origen de su Escuela.

Ortega quería reformar la Universidad, y reformar la filosofía. Ortega

37. W. Dilthey, Teoría de las concepciones del mundo, Editorial de la «Revista de Occidente», 1. ${ }^{\text {a }}$ edic. $1944,2{ }^{\text {a }}$ edic. 1974 , pág. 41.

38. Julián MARIAS, Comentarios, prefacio a la edic. de 1974 de «Teoria de las concepciones del mundo». 
con el entusiasmo que le caracterizaba, inició el período constituyente de la única escuela filosófica de nuestro país. Este empeño cobra un valor especial al producirse en una "España invertebrada» en un "país de adanes», donde cada intelectual quiere comenzar desde cero sin tener en cuenta los trabajos anteriores. Quizá esta sea la razón de que seamos un país de "frágil memoria», que olvida a sus hombres más importantes y por su pesimismo inveterado se auto-convence de la inexistencia de hombres de valía. Laín tuvo que salir al paso ante los terribles efectos de este pesimismo nacional, recordándonos que en España hay, o los hubo hace poco, «más de cien españoles» ilustres.

D. Nicolás Salmerón, expresidente de la República, fue el precursor de Ortega en la cátedra de Metafísica. Frente a las agresiones del Gobierno, censor de la libertad de cátedra, Salmerón, Giner de los Ríos, Castelar, Gumersindo de Azcárate, etc. dimitieron de sus puestos en la Universidad. El volcán de la «Cuestión Universitaria», desatada por el Gobierno, dejó la Universidad rota.

Ortega, Morente, y un grupo valioso de profesores y estudiantes tenían la misión de construir una nueva Universidad sobre las ruinas de la antigua. Esta misión era coincidente con la de salvar a España, porque «no hay nación grande, dirá Ortega, si su escurela es mala» ${ }^{39}$.

Los preámbulos de la Escuela de Madrid podrían encontrarse quizás en la escuela Superior de Magisterio, donde Ortega dio clases con anterioridad. Sucedió, nos cuenta Mindán, que el Sr. Barnés, profesor de esta Escuela fue nombrado ministro. Acto seguido, el nuevo ministro dio un decreto por el que hacía catedráticos de la Facultad de Pedagogía y con la antigüedad que tuvieran en la Escuela Superior de Magisterio, a él y a todos sus compañeros. Ortega había conectado aquí con algunos profesores.

Creía Ortega que para llevar a cabo una renovación de la Universidad, antes había que tener una idea clara de la misión de esta Universidad: "Una institución es una máquina y toda su estructura y funcionamiento han de ser perfilados por el servicio que de ella se espera. En otras palabras: la raíz de la reforma universitaria está en acertar plenamente con su misión» ${ }^{40}$.

La reforma no puede consistir en un parchear las deficiencias, debería hacerse una auténtica creación de una nueva forma de entender la educación y la misión de la Universidad: «La reforma universitaria no puede reducirse a la

39. José OrTEGa y GASSET, Misión de la Universidad y otros ensayos afines. Madrid 1965 , pág. 19.

40. José Ortega y Gasset, Misión de la Universidad y otros ensayos afines, pág. 17. 
corrección de abusos, afirma Ortega, ni siquiera consistir principalmente en ello. Reforma es siempre creación de usos nuevos" ${ }^{41}$.

En los últimos años no se ha abordado la cuestión universitaria con profundidad. Todo lo más, se han of recido unas malas copias de lo que existe en las Universidades de otros países. No se trata, añade Ortega de que no nos informemos de lo que existe en otros países, al contrario, tenemos el deber de estar bien informados. Pero, tenemos que resolver nuestro propio problema, delimitado por unas circunstancias muy precisas y distinto del problema universitario de otros países. Por lo tanto, no es cuestión de copiar, sino de estudiar profundamente la problemática, de dejar mandar a la imaginación, «el poder del intelectual». «Entre estos intentos de los últimos quince años..., en vez de plantearse directamente, sin permitirse escape, la cuestión de «¿para qué existe, o está ahí y tiene que estar la Universidad?», han hecho lo más cómodo y lo más estéril: mirar lo que ya se hacía en las Universidades de otros pueblos ejemplares... No importa que lleguemos a las mismas conclusiones y formas de otros países; lo importante es que lleguemos a ellas por nuestro pie, tras personal combate con la cuestión sustantiva misma» ${ }^{42}$.

La Universidad contemporánea, en opinión de Ortega, ha cometido una verdadera atrocidad: ha complicado tanto el sistema de especializaciones que se ha olvidado de su papel fundamental: transmitir la cultura. «Por eso es ineludible crear de nuevo la enseñanza de la cultura o sistema de las ideas vivas que el tiempo posee. Ésta es la tarea universitaria radical. Eso tiene que ser antes y más que ninguna otra cosa la universidad» ${ }^{43}$.

Para orientarse en la vida hay que ser culto. La vida es complicada y es preciso acertar con el método. La cultura o se recibe o la inventamos. Aquel que pueda inventarla, olvidando treinta siglos de producción intelectual, podría negar el papel de la Universidad, pero los que no podamos ignorar radicalmente el pasado, dice Ortega, tendremos que admitir la Universidad.' «Hace bastantes años, en 1930, dio Ortega una conferencia a los estudiantes de la Universidad madrileña que recogida y ampliada luego en un libro, bajo el título de «Misión de la Universidad», ha podido influir en algunas reformas posteriores... No creo que el propósito y las actividades de esta Aula de Cultura (donde Garagorri está hablando) de la Universidad de Madrid, sean ajenos a aquel proyecto. Más bien presumo, proceden de él y persiguen, en alguna medida, los mismos fines» ${ }^{44}$.

\footnotetext{
41. José Ortega y Gasset, Misión de la Universidad..., pág. 16.

42. José ORTEga y GASSET, Misión de la Universidad..., pág. 18.

43. José Ortega y Gasset, Misión de la Universidad..., págs. 31 y 32.

44. Paulino Garagorri, Introducción a Ortega, Alianza Editorial, Madrid 1970, págs. 13-
} 14 
Por estas fechas, la Facultad de Filosofía, asegura Aranguren, era absolutamente orteguiana: «Incluso Besteiro, profesor mío, de Marías y de todos nosotros, funcionaba en la Facultad como alguien que giraba enteramente en la órbita de Ortega. En Besteiro, dice Aranguren, se daba una especie de escisión de la personalidad; por una parte, era socialista - todo lo moderado que se quiera-, pero en la Facultad era uno más de los que giraban en torno a Ortèga».

Si Fernando Vela era colaborador infatigable y hombre de responsabilidad de la empresa periodística de Ortega, García Morente participaría en dos frentes: uno, en el mundo de las publicaciones, otro en el mundo universitario: «Morente gozaba de una gran confianza por parte de mi padre, tanto en la gestión universitaria, como en sus trabajos de la Revista de Occidente», nos asegura José Ortega (hijo).

Morente dio un curso dialogado en el Palacio de Liria. Era un curso sólo para mujeres y se impartía mientras tomaban el té. Morente sería, pues, el Descartes español, tanto por su claridad, cuanto por dar lecciones a la alta sociedad.

Morente, «máximo colaborador de Ortega», llevó adelante la reforma universitaria con toda la calidad y método que él solía poner en las tareas. El filósofo de la claridad resultó ser además un excelente decano: «...Era decano el inolvidable. D. Manuel García Morente», nos dice D. Manuel Mindán ${ }^{45}$.

El «Plan Morente» exigía un examen para ingresar en la Universidad. Ofrecía, después, un cupo de asignaturas y el estudiante escogía cada año el número de ellas según sus deseos. Antes de obtener la Licenciatura, el estudiante debía haber cursado todas las asignaturas. Estos estudios no podían hacerse en menos de tres años, pero los estudiantes, comenta el profesor Mindán, no tenían ninguna prisa por terminar. El Plan Morente suprimió los exámenes durante los cursos normales, sólo había exámenes, tremendos exámenes, al final de la carrera para obtener la Licenciatura.

Estos exámenes finales consistían en tres ejercicios escritos, de cuatro horas de duración y todos ellos eliminatorios. El primero consistía en desarrollar un tema escogido entre dos, sacados al azar. El segundo, trataba de un comentario de dos textos filosóficos, uno en griego y otro en latín (se suponía que el alumno conocía correctamente estos dos idiomas). En el tercero había que desarrollar un tema de Historia de la filosofía.

Superados estos tres exámenes, se pasaba al examen oral que era; si cabe, más terrible. En ocasiones componían el tribunal: Ortega, Besteiro; Morente,

45. Manuel MindáN, «Revista de filosofía», números 60-61. Año 1957, pág. 142. Nos hemos servido del artículo del profesor Mindán publicado en este número y de los datos que nos facilitó en una entrevista, para reconstruir el Plan Morente. 
Zubiri y Zaragüeta. Cualquiera temblaría ante un tribunal así. El examen versaba sobre todas las materias no examinadas antes por escrito. Se elegía una papeleta y se hablaba sobre el tema señalado en la misma, durante diez minutos; después venían las preguntas del tribunal. Examinadas las distintas materias, se llegaba a la última prueba, consistente en la exposición de un tema que no fuera de la especialidad de filosofía; al examinarse esta última asignatura, se permitía una encerrona previa.

Los cursos eran monográficos, no se seguía un programa fijo. Cada año, a fin de curso, se editaba un folleto en el que se anotaban las materias a impartir en el curso siguiente. Se podía elegir profesor, por lo que los propios alumnos seleccionaban realmente sus profesores.

La Universidad, asegura Mindán, tuvo en estos años un profesorado excepcional. «Ortega fue, ante todo un profesor de extraordinaria brillantez que logró interesar vivamente a sus alumnos y que ejerció un gran influjo en los medios universitarios» ${ }^{46}$.

Mindán renunció a su cátedra para acudir a Madrid a escuchar los cursos de Ortega. Cuando D. José conoció las circunstancias que rodeaban al alumno Mindán y lo mal que andaba de dinero, se interesó muy personalmente por él, y le ofreció algunos trabajos en la Revista de Occidente.

"Comencé a asistir a las clases de la Facultad de Filosofía y Letras en otoño de 1934, nos comenta D. Manuel Mindán. Seguí mis estudios con normalidad aquel curso y el siguiente hasta el mes de junio de 1936. Las clases se daban ya en el nuevo edificio de la Ciudad Universitaria que estaba sin terminar». Morente tenía mucho interés en estrenar estos nuevos edificios que darían a la Universidad un aire nuevo, acorde con la novedad de las reformas que estaban efectuándose. Si hoy día se aplicase el plan Morente, se produciría probablemente una revolución educativa.

Mịnán heredó de Morente la claridad de pensamiento y la nitidez en la expresión hablada y escrita. D. Manuel fue también profesor de profesores -Pinillos, Yela, González, etc. - en la Universidad de Madrid. Otros discípulos de Ortega también llegaron a ser profesores de la Universidad de Madrid.

«D. Manuel García Morente, con aquel orden y claridad tan extraordina-

46. Manuel Mindán, El último curso de Ortega en la Universidad de Madrid: Principios de metafísica según la razón vital, en «Revista de filosofía, números 60-61, pág. 141. (Estos dos números de la Revista de filosofía están dedicados a Ortega. Manuel Mindán, director de la revista propició la confección de estos números en los que colaboraron: Juan Zaragủeta, con «El vitalismo de Ortega», Eugenio Frutos, con «La idea del hombre en Ortega y Gasset», Carlos París con «El concepto de ciencia natural en Ortega», José Camón Aznar con «Ortega ante el arte», Francisco Maldonado de Guevara con «El lenguaje en Ortega». Emilio Lledó: «Filosofía» y «Éxito», dos palabras sobre Ortega en Alemania). 
rias en él, explicó en sus clases de Ética, un año, «la teoría de la libertad», y al año siguiente «la teoría de los valores» ${ }^{47}$.

No eran muy numerosos los estudiantes de la sección de Filosofía, pero la calidad de los profesores atraía a estudiantes de otras Facultades o Escuelas, que venian a escuchar algunas clases.

Zubiri «fue un excelente profesor, Besteiro, catedrático de Lógica, era, según Mindán, «más político que filosófico». Gaos en cambio, aunque también era socialista, «fue y es, más filósofo que político». Gaos explicaba «Introducción a la Filosofía». Esta asignatura tenía dos partes. «En esta segunda parte (Teoría y Didáctica de la Literatura) colaboraba el Prof. Montesinos que se sentaba en el estrado para los oportunos asesoramientos e ilustraciones literarias. En esta clase vi alguna vez al mismo Ortega y Gasset sentado junto a mí en los bancos de los alumnos» ${ }^{48}$.

La Psicología la impartía D. Lucio Gil Fagoaga, que andaba al parecer, un poco escaso de alumnos. Explicaba Estética D. Hilario Ayuso. la Sociología estaba a cargo de D. Severino Aznar.

D. Juan Zaragüeta, aunque pertenecía a la sección de Pedagogía, «llevado por su evidente vocación filosófica, siempre explicaba algún curso para estudiantes filósofos».

Los alumnos de entonces, son ahora prestigiosos profesores. Ellos son los pilares de la Escuela de Madrid. Los límites de este trabajo no nos permiten hablar detenidamente de cada uno de ellos, aunque sean merecedores de una larga mención.

Antonio Rodríguez Huéscar leía en clase algunos textos que luego se comentarían. En ocasiones, los párrafos escogidos pertenecían a Bergson. Se leían en francés. Posteriormente se traducían y se hacían los comentarios pertinentes. Ortega decía la última palabra.

Agustín Minguijón le prestó a Mindán las notas de clase para completar el «último curso de Ortega».

Mencionamos también a Benavent, hoy Vicario general castrense, a Antonio Salvador de la Cruz, a Granell, a Julián Marías, a Palacios, etc.

Entre las alumnas, recordamos a: Soledad Ortega, Lolita Franco, y María Araujo. Más adelante hablaremos de María Zambrano, alumna y profesora ayudante de Ortega.

«En el mismo curso se publicó una revista, redactada también por los alumnos, titulada Cuadernos de Filosofía y Letras. Salieron cuatro números.

47. Manuel Mindán, El último curso de Ortega en la Universidad de Madrid: Principios de metafísica según la razón vital, en «Revista de filosofía», números 60-61, pág. 145 .

48. Manuel Mindán, El último curso de Ortega en la Universidad de Madrid..., pág. 145. 
Era redactor jefe Darío Fernández Flórez, y secretaria, María Rosa Alonso. Figuraban como representantes de las distintas secciones: Julián Marías, por Filosofía; Carlos Alonso del Real, por Letras Clásicas; Luis Rosales, por Letras Modernas; el mismo Darío Fernández Flórez, por Historia, y Anselmo Romero, por Pedagogía. Y colaboraron en ellas además de los dichos, Antonio Tovar, Leopoldo E. Palacios, E. E. Benavent, Marañón Moya y otros» ${ }^{49}$.

Ortega contó con un reducido número de alumnos, entre quince y treinta, que era lo que se estilaba por aquellos tiempos en los que no se había producido La rebelión de las masas. El joven maestro daba tres tipos de clases: El primero, titulado "Principios de metafísica», lo hacía los martes de seis a siete de la tarde. Los miércoles de doce a una, explicaba otra clase a un auditorio más restringido, sobre «Estructura de la vida histórica y social».

La tercera clase era más bien un Seminario sobre problemas filosóficos concretos. Si la segunda clase era para un público (más) reducido, esta tercera era sólo para los elegidos y se celebraba en la sede de la Revista de Occidente. En realidad, más que una clase era una tertulia. Ortega necesitaba la tertulia como el aire. Bien en el Ateneo - «donde Unamuno ponía su yo mastodóntico sobre la mesa»-, bien en la Revista, Ortega precisaba la tertulia como fuente de información y como canal de comunicación. Al parecer, Gaos seleccionaba en ocasiones las personas que asistirían a la tertulia de la Revista.

«Para las recientes generaciones que nunca pudieron asistir a sus clases, se presenta así la ocasión de asistir a estas páginas a la creación y formulación de un pensamiento original que, durante veinticinco años (1910 a 1935/36) elevó la enseñanza de la Filosofía en la Universidad española a las más altas cimas» ${ }^{50}$.

Los que no pudimos asistir a las clases de Ortega, podemos «escucharlas» a través de los libros en que estas clases están recogidas. Naturalmente, no será lo mismo porque falta la presencia física del filósofo, pero su intento de diálogo, de "plantearse al prójimo» vive entre las líneas de sus lecciones escritas.

«Para la comprensión del pensamiento filosófico de Ortega, sus cursos universitarios constituyen un elemento decisivo. Y en este curso (1932-33) - por ser uno de los últimos que pudo desarrollar - la exposición de su filosofía se realiza desde un nivel de madurez en un sistema filosófico" ${ }^{51}$.

Las catorce lecciones, casi dialogadas, recogidas en Unas lecciones de me-

49. Manuel Mindán, El último curso de Ortega en la Universidad de Madrid: Principios de metafísica según la razón vital, pág. 143.

50. Paulino Garagorri, Nota preliminar, en «Unas lecciones de metafísica», «Revista de Occidente», 1974, pág. 11.

51. Paulino Garagorri', Nota preliminar, pág. 12. 
tafísica, van de «lo oscuro a lo claro», siempre a la búsqueda de la verdad, generando constantemente luz: «¿Qué es, pues, vida? No busquen ustedes lejos, nos dice Ortega, no traten de recordar sabidurías aprendidas. Las verdades fundamentales tienen que estar siempre a la mano, porque sólo así son fundamentales. Las que es preciso ir a buscar es que están en un sitio, que son verdades particulares, localizadas, de rincón, no básicas. Vida es lo que somos y lo que hacemos: es, pues, de todas las cosas la más próxima a cada cual. Pongamos la mano sobre ella, se dejará apresar como un ave mansa... La vida es lo que hacemos y lo que nos pasa» ${ }^{52}$.

El hombre es proyectarse hacia el futuro. Proyectivismo y perspectivismo son los dos focos de la elipse de la vida. Porque la vida no es circular, sino elíptica como las órbitas de los planetas, como un cohete viviente proyectado -apuntado- hacia el futuro: «nuestra vida es ante todo toparse con el futuro. No es el presente o el pasado lo primero que vivimos, no: La vida es una actividad que se ejecuta hacia adelante, y el presente o el pasado se descubren después, en relación con ese futuro»" ${ }^{53}$.

Nuestra vida tiene caracteres geométricos, igual que la vida de los egipcios y de los pitagóricos y de los toreros que se la juegan geométricamente, sobre un espacio donde «el toro es la horizontal y el hombre la vertical». Todo lo que vemos, lo vemos desde nuestro punto de mira, desde la ventana de nuestra circunstancia, desde la atalaya de nuestra vida sita en El gran teatro del mundo. El teatro y los toros decía Ortega, son los dos arquetipos del pueblos español. «Yo soy torero; digo que hay que comprender al toro, afirmo que entiendo de toros, aseguraba Ortega, porque los especialistas en la materia vienen a escucharme»: "Se trata de las dos máximas creaciones artísticas de nuestro pueblo en aquel siglo: Las corridas de toros y el teatro» ${ }^{54}$.

La metafísica es la concepción del mundo, la comprensión de la vida, es jugarse la vida con los toreros de Heminguay. En nuestro país, los nobles envidiaron los festejos taurinos, el teatro y las verbenas del pueblo, porque el pueblo se arrima más al toro, se juega más las vida en la plaza de la perspectiva y del proyecto. Hace seis siglos que san Fermín lo está explicando milagrosamente: «La fiesta de toros, dice Bergamín, es injustificable, es decir, milagrosa».

Hegel al hablar de las cosas más importantes de la vida, hace una importante referencia a la poesía española. Se refería, sin duda al teatro-poesía de Lope, de Calderón...

52. José Ortega y GaSSET, Unas lecciones de metafísica, págs. 39-40.

53. José ORTEga y GASSet, Unas lecciones de metafísica, Ed. «Revista de Occidente», 1974, pág. 49.

54. José Ortega y Gasset, Goya, Ed. Espasa-Calpe, 1970, pág. 51. 
Hace trescientos años que se jugó la vida «verso a verso» D. Pedro Calderón de la Barca Hernao de la Barrera Riaño:

« ¿Qué os admira? ¿Qué os espanta, si fue mi maestro el sueño, y estoy temiendo en mis ansias que he de despertar y hallarme otra vez en mi cerrada prisión? Y cuando no sea, el soñarlo sólo basta» $\$$.

Calderón iluminó a golpe rimado de luz los sótanos sacramentales, románicos y galantes del pueblo español.

«En febrero de 1929, dice Ortega, comencé un curso en la Universidad de Madrid titulado ¿Qué es filosofía? El cierre de la Universidad por causas políticas y mi dimisión consiguiente me obligaron a continuarlo en la profanidad de un teatro"s".

Teatro y filosofía de la vida son «dioses unánimes que nacen y mueren juntos».

Las lecciones segunda y sexta las pronunció el maestro en la Sala Rex, y a partir de la séptima, a causa de la gran afluencia de público, en el teatro Infanta Beatriz.

Los últimos párrafos de la lección dos de «Unas lecciones de metafísica son un comentario a la lección diez publicada en ¿Qué es filosofía?: "Si no nos es dado escoger el mundo en que va a deslizarse nuestra vida - y ésta es su dimensión de fatalidad - nos encontramos con un cierto margen, con un horizonte vital de posibilidades - y ésta es su dimensión de libertad-; la vida es, pues, la libertad en la fatalidad y la fatalidad en la libertad» ${ }^{57}$.

Otra lección de Ortega... «la primera parte de este libro (El tema de nuestro tiempo) contienen la redacción, un poco ampliada, de la lección universitaria con que inauguré mi curso habitual en el ejercicio de 1921-1922» ${ }^{58}$.

Para redactarla ahora me he servido de los apuntes minuciosos y correctísimos que tomó en el aula uno de mis oyentes, mi querido amigo, don Fernando Vela»s ${ }^{59}$.

Cultura o espontaneidad, Sócrates o don Juan. Éste es el binomio que encierra en su seno al dios creador y al dios destructor: «Nunca han faltado a la vida humana sus dos dimensiones: cultura y espontaneidad, pero sólo en

55. Pedro Calderón de la Barca, La vida es sueño. Espasa-Calpe, 1977, pág. 125.

56. José Ortega y Gasset, ¿Qué es filosofía?, 1973, pág. 11.

57. José ORTEGa y GASSET, ¿Qué es filosofía? pág. 193.

58. José Ortega y Gasset, El tema de nuestro tiempo. Espasa-Calpe, 1975, pág. 9.

59. José Ortega y Gasset, El tema de nuestro tiempo, pág. 9. 
Europa han llegado a plena diferenciación, disociándose hasta el punto de constituir dos polos antagónicos.

...Toda la gracia y el dolor de la historia europea provienen, acaso, de la extrema disyunción y antítesis a que se han llevado ambos términos. L.a cultura, la razón, ha sido purificada hasta el límite último, hasta romper casi su comunicación con la vida espontánea, la cual, por su parte, quedaba, también exenta, brava y como en un estado primigenio. En esta superlativa tensión se ha originado el incomparable dinamismo, la inagotable peripecia y la permanente vibración en nuestra historia continental» "i".

"Julián Marías conoce perfectamente la obra de mi padre, nos confiesa José Ortega Spottorno. Marías, en un principio, fue un tanto zubiriano. Su mujer era más orteguiana, y ella fue la que llevó a Marías al sector orteguista» ${ }^{61}$.

La cultura española, escribe Julián Marías, es una «cultura de adanes». acostumbrados a «comenzar desde cero» sin tener en cuenta lo hecho antes: «La cultura española es una cultura fronteriza, insegura, impresionista, sin continuidad». La Escuela de Madrid tiene el propósito de corregir este viejo error, quiere asegurar que no van a guardarse en el arcón del olvido los hallazgos filosóficos del siglo XX. Hay que procurar la vertebración, la continuidad, dice Marías. No tenemos derecho de retroceder hasta cero para olvidar las aportaciones culturales anteriores. Respecto a Ortega, este olvido ha sido una pertinaz tentación, pero parece que afortunadamente va a ser superada.

En su ensayo «La Escuela de Madrid» habla Marías de sus maestros.

Es difícil de precisar la importancia actual de la Escuela de Madrid. Existen discípulos ortodoxos - Marías, Rodríguez Huéscar, etc.-, pero éstos no son muy numerosos. Ahora bien, un influjo importante de Ortega y sus discípulos en la cultura española es innegable. Sucede lo mismo, mutatis mutandis, que en el caso del marxismo. Apenas quedan discípulos ortodoxos de Marx, si es que queda alguno, pero una cierta influencia de Marx, dice Aranguren, en la cultura occidental es una verdad incuestionable.

En su ensayo sobre la ética de Ortega, Aranguren lo explica así: «En rigor, este trabajo no está escrito desde la filosofía orteguiana, aunque mi deuda a Ortega sea, ciertamente muy grande. Todos los españoles que pensamos y escribimos en nuestro tiempo hemos recibido generosamente la influencia orteguiana. La presencia de Ortega en las letras y en el pensamiento de nuestro país ha sido tan central que nadie ha podido sustraerse a ella, si bien en algunos casos la irradiación haya operado a bastante distancia, de manera difusa,

60. José Ortega y Gasset, El tema de nuestro tiempo, pág. 9.

61. Agradecemos a Julián Marías la bibliografía facilitada. 
con una recepción débilmente consciente; y en otros, el efecto se advierte, sobre todo, por la reacción, o por la voluntad de su ocultamiento" 6:.

Julián Marías hace autobiografía. En realidad, casi todos los autores, hacen autobiografía, más o menos directamente cuando escriben. Si son auténticos, si ponen lo que llevan dentro en sus páginas, su obra tendrá un cierto carácter autobiográfico.

"...Conocí, afirma Marías, a un número sorprendentemente alto de intelectuales, escritores y artistas de aquellos años... Participé en el crucero universitario que en 1933 organizó la Facultad de Filosofía y Letras, dirigida por D. Manuel García Morente... El Sol publicó en 1933 mis primera páginas impresas: el prólogo al diario del crucero, que había de aparecer al año siguiente editado por Espasa Calpe. En 1934 se publicó por la Revista de Occidente mi primera traducción, con un prólogo: Discurso sobre el espíritu positivo, de Auguste Comte; al año siguiente, la Revista de Pedagogía, que dirigía Lorenzo Luzuriaga, publicó mi primera traducción del alemán: Introducción a la filosofía de Rudolf Lehmann. Por esto puedo dar una impresión vivaz y de primera mano, no libresca, de lo que fue el ambiente intelectual, especialmente universitario, hace medio siglo» ${ }^{6 .}$.

Ortega, comenta Marías, se dirigía a las generaciones futuras, a la mal llamada generación del 27 , de la que Ortega se consideraba «su hermano mayor».

De acuerdo con la calidad del temple y con el momento, en la obra orteguiana «habrá zonas de aridez y habrá partos que llevan un trozo de su alma». Cuando no estaba en temple, Ortega era espectador: tomaba notas, observaba... Cuando el temple llegaba era autor y actor.

«La razón no puede sustituir la vida, dirá Julián Marías, pero la razón es una función vital como la vista». «El concepto es el doble de cada ser», fija y positiva las cosas. La cultura es una labor de «interpretación — positivaciónde la vida», por eso Ortega, el filósofo de la cultura, quería que hablasen de su «racio-vitalismo», de la «razón vital».

Según Marías, el método de Ortega es el «método Jericó» dar vueltas alrededor de las cosas, verlas desde distintas perspectivas. «Recuerdo, comenta Marías, que cuando hacíamos intervenciones en clase, aun cuando fueran afortunadas, el maestro solía decir: «está bien. Pero, siga, siga, déle vueltas».

El perspectivismo orteguiano es antidogmático: la perspectiva que se afirme como la única tiene muchas probabilidades de ser falsa.

\footnotetext{
62. José Luis l. Aranguren, La ética de Ortega. «Cuadernos Taurus», 1959, pág. 12.

63. Julián MARÍAs. La vida en España durante la República / 1. En «el País», 9 de julio de 1981 .
} 
Una lectura superficial de Ortega podrá conducir a la conclusión de que se trata simplemente de un buen literato. Se trata de un espejismo que se disipará con una lectura atenta y sin prejuicios de los escritos de uno de los primeros filósofos de España. Ortega es un filósofo que se expresa literariamente por exigencias de su propio pensamiento - un pensamiento creativo--. Utiliza bellísimas y muy acertadas metáforas. Pero reprochar a un filósofo que escriba literariamente y utilice metáforas, parece, por lo menos, improcedente. Metáforas utilizó el viejo Parménides, el luminoso Heráclito, el divino Platón, Bergson, Sartre, Heidegger y un sinfín de filósofos, que tenían, a la vez, una excelente calidad literaria.

La metáfora es un instrumento de primera mano para un filósofo creador, que debe poner nombre a lo creado.

Julián Marías explica la metáfora en Ortega, en el punto 2 de su libro Ortega. Circunstancia y Vocación. 2.

Ortega creó con Julián Marías el «Instituto de Humanidades», «un instituto de historia, pero por historia, dirá Ortega, entiendo el estudio de la realidad humana desde el más remoto pasado hasta los hombres presentes inclusive. Por tanto, no hay tema ni habrá tema en nuestro Instituto que no tenga una dimensión de actualidad» ${ }^{64}$.

Temporalidad, historidad y racio-vitalismo no son realidades disociadas, sino compañeros de viaje: «Porque historia es entender bien las realidades humanas a que esos documentos aluden y que esos documentos son. ... Es la historia todavía una ciencia adolescente que con frecuencia balbucea. Mas siendo ella por antonomasia la ciencia del hombre y entrando éste ahora en una etapa sobremanera crítica de sus destinos, tenemos el deber de hacer un esfuerzo enérgico y perentorio para transformarla en una ciencia adulta. Éste es el propósito central que me llevó a iniciar nuestro Instituto de Humanidades» ${ }^{65}$.

«Zubiri también es un discípulo importante de Ortega. Además ejerció bastante influencia en algunos discípulos de mi padre», afirma el Sr. Ortega Spottorno.

Con Zubiri la filosofía alcanza las cotas de dificultad más altas dentro de la Escuela de Madrid. Zubiri escribe sólo para ya iniciados. Cuentan que cuando Zubiri daba una clase, un alumno que llegó tarde preguntó a su compañera de pupitre: ¿qué tal? Genial, contestó ella, no entiendo nada.

El autor de Naturaleza, historia y Dios es un filósofo denso, al que hay que acercarse poco a poco, pero, a la vez, un pensador certero, exacto en plan-

64. José Ortega y GaSSET, «Obras Completas», «Revista de Occidente», vol. 9, pág. 74.

65. José Ortega y GASSET, «Obras Completas», vol. 9, pág. 75. 
teamiento de las cuestiones y que orienta al lector hacia la verdadera raiz de la problemática.

Podríamos proponer como eiemplo de lo dicho anteriormente algunos textos de Zubiri sobre Dilthey.

"Dilthey, gran cultivador de la historia, se enfrenta con la filosofía desde un punto de vista histórico relativamente nuevo; sólo relativamente, porque la concepción sociológica de Augusto Comte influye profundamente en su espíritu. Este punto es completamente opuesto al de Hegel: la filosofía no es obra de la razón absoluta, sino de la vida humana. Dilthey es un gran teórico de la vida. En su concepción de la vida, Dilthey acusa la influencia de la filosofía y psicología francesas» ${ }^{\text {th }}$.

Existe un importante zubiriano con un papel muy destacado dentro de la Escuela de Madrid, ya que fue rector de la Universidad. Se trata de Pedro l aín. «Laín, asegura Aranguren, no querría ser considerado heterodoxo del orteguismo; de todos modos, Laín es mucho más zubiriano que orteguiano. Tiene por Zubiri una devoción sin límites. Claro, en la medida que Zubiri también viene de Ortega, se le puede considerar orteguiano. Pero, I aín es un hombre absolutamente de Zubiri».

Para conocer bien a Zubiri, indica Laín, conviene leer las páginas finales del estudio «Hegel y el problema inetafísico»: «La tercera metáfora sobre el ser humano que en ellas se propone - el hombre como «la auténtica, la verdadera luz de las cosas»- le ayudará a comprender la personal situación de $\mathrm{Zu}$ biri en la historia de la filosofía»" 17.

Vida e historicidad son dos conceptos importantes en Dilthey, que Zubiri explica así: «La vida... se ve impulsada a una concepción unitaria del mundo, de los valores, de las acciones. Esta concepción unitaria pertenece a la vida por la propia estructura de ésta. Y a esta concepción es a la que temáticamente llama Dilthey «concepción del mundo».

...De ahí que la única forma que se presenta la filosofía como problema es la historicidad" ${ }^{68}$.

Dentro de este breve comentario de la Escuela de Madrid, no podrían faltar unas líneas sobre uno de los discípulos más queridos de Ortega, Antonio Rodríguez Huéscar, uno de los orteguianos más ortodoxos.

«Mi padre se interesó muy pronto por el alumno Rodríguez Huéscar y le invitó a las tertulias de la Revista de Occidente, que, como saben, se reserva-

66. Xavier Zubirı, Cinco lecciones de filosofía. Alianza Editorial, 1980, pág. 247.

67. Pedro Laín EnTralgo. Más de cien españoles, 1981, pág. 189.

68. Xavier ZuBırı. Cinco lecciones de filosofía, págs. 250, 253. 
ban a los colaboradores. Rodríguez. Huéscar tiene importantes escritos sobre mi padre ${ }^{64}$, afirma José Ortega (hijo).

Antonio Rodríguez. Huéscar pronunció recientemente una excelente conferencia sobre Ortega ". Dijo que «Ortega estaba instalado en algo parecido a lo que en Alemania comenzó a llamarse fillosofía de la existencia». Habló de la filosofía de Ortega como una superación del idealismo. "Cuando Ortega tenía 27 años una de sus metas principales era ya superar el idealismo".

Rodríguez Huéscar analizó Meditaciones del Quijote, que significa la entrada de Ortega en la esfera de los grandes ensayistas.

Otros escritores, relativamente ortodoxos del orteguismo, prolongaron los análisis de Ortega sobre arte, literatura, etc.: «Los análisis que hace Ortega sobre pintura española -Gova, Velázquez-. o sobre teatro, me gustan, comenta Aranguren. Están bien. Son trabajos agudos. Luis Díez del Corral es el que ha continuado esta linea. A Díez del Corral también puede considerársele discípulo de Ortega. Tiene bonitos libros sobre Velázquez. Ya no es un orteguiano estricto, igual que Maravall. En primer lugar, ninguno de los dos es propiamente filósofo, y en segundo lugar, cuentan con otras muchas influencias además de las orteguianas».

Ortega tuvo y tiene un redoblado eco en Hispanoamérica. Manuel Granell aprendió de Ortega el camino hacia las realidades mismas. Quizás leyó a Husserl entre algunas líneas de Ortega. Granell estudió en Oviedo y, luego, en Madrid con Ortega. Pero donde él está ejerciendo la docencia es en Hispanoamérica - Universidad Central de Venezuela.

Granell se adentra en los campos de la Lógica, la Antropología y la Etología. Es un cualificado emisario orteguiano en Hispanoamérica.

Sería tarea larga hablar con detalle de todos y cada uno de los discípulos de Ortega. No obstante, queremos dedicar unas ilusionadas líneas a un verdadero artesano del lenguaje, a un querido filósofo francés que «se consideraba discípulo de Ortega». «Si, he de decirles que Camus se consideraba discípulo de Ortega, afirma José $O$ tega Spottorno. Él lo confesó algún tiempo antes de morir mi padre. Yo tuve una entrevista con Camus, continúa José Ortega; Camus hablaba muy bien el castellano porque descendía de españoles por línea materna. Se interesó por las publicaciones de Ortega y me preguntó si conservábamos las pruebas de imprenta. Dijo que en Francia siempre se conservan, e incluso se venden como tales. En Francia, añadió Camus, se tiene mucho res-

69. Antonio Rodriguez HuésCar, Con Ortega y otros escritos. Taurus. Madrid 1964. (Obtuvo el premio «Ortega y Gasset» 1981).

70. La Sociedad de España de profesores de filosofía del Instituto organizó en el curso 8081 una Semana sobre Ortega, en la que participaron destacados filósofos españoles. 
peto a la imprenta. Las cartas mismas, continuó, se escriben, a veces, pensando más en su posible publicación que en su destinatario».

La editorial francesa Gallimard firmó un contrato para publicar las Obras completas de Ortega. Contrato que ciertamente incumplió. Cuando murió Camus, viajaba en compañía de un miembro de la editorial Gallimard. "No sé exactamente, continúa Ortega Spottorno, qué aspecto de la obra de Ortega atraía a Camus. Quizás fuera su autenticidad, su idea de la vida..., no lo sé. Tampoco sabría decir si Ortega se adelantó o no al existencialismo. Sobre esta cuestión, les sugiero que analicen detenidamente el libro de Fernando G. Vela, Ortega y los existencialismos.

Quizás el factor común a Camus y Ortega sea su entusiasmo por lo humano, porque, a pesar de todo, «en el hombre existen más cosas dignas de admiración que de desprecio».

Si leemos, por ejemplo, «La Peste» desde una perspectiva orteguiana, podremos descubrir perfectamente las características del actor y del espectador. El periodista - posiblemente simbolice al propio Camus- puede ser un frío espectador - informador-de los problemas de la peste. Pero. llegado un momento, puede llegar a comprometerse, a participar del sufrimiento de los apestados. Se produce aquí un cambio importante que afecta al proyecto de vida, y que modifica el campo de fuerzas. Camus pasa revista a los actores y espectadores de las distintas clases sociales. La libertad humana podría entenderse como la capacidad de proyectar su vida ya como actor ya como espectador.

"María Zambrano ${ }^{71}$ es una mujer excepcional», afirma Aranguren. Fue discípula de Ortega y profesora en la cátedra de Metafísica. En aquel tiempo, en que el número de alumnas era escaso, María tuvo el mérito de ser profesora dentro de un equipo envidiable. «María Zambrano escribe páginas místicopoéticas que difieren bastante de lo que hacen los orteguianos ortodoxos. Si bien ella se considera orteguiana, es un orteguismo muy particular» (Aranguren).

Orteguismo místico y mítico, menos racionalista que la obra del maestro. Sin llegar a ser propiamente feminista, María Zambrano cultiva indudablemente perfiles femeninos.

María se exilió en 1939, y estamos esperando ahora su anunciado -e intensamente deseado por algunos españoles- regreso.

Recientemente se la concedió el premio «Príncipe de Asturias», premio

71. María Zambrano, Pensamiento y poesía en la vida española, F.C.E., México 1939. (Maria ha hecho recientemente declaraciones a la prensa y a la radio españolas en relación con su regreso). 
que aceptó porque, según confiesa: «Somos muchos los que aceptamos la situación de España, es decir, la forma de hacer del rey y de sus colaboradores».

«María Zambrano, dice Cela, me parece una de las mejores cabezas de todos los tiempos. Las tres personas que más me ayudaron en mis comienzos fueron ella, Pedro Salinas y Pablo Neruda. ...Cuando la vi en Ginebra el año pasado, me regaló la fotocopia de unos versos mios del año 1934, muy influidos por Juan Ramón (Jiménez.) en el espiritu y por Alberti en la forma».

El poeta Valente está trabajando duro en la preparación del regreso de María Zambrano. Valente se queja de la poca atención que en España se ha prestado a esta pensadora orteguiana: «A raiz de la publicación del primer volumen de Ohras reunidas en ediciones Aguilar, sólo hubo dos respuestas en España. Una, la mia, vino de fuera. La otra, escrita por Aranguren, de dentro. A partir de ese instante, el pensamiento de María empieza a ser oído».

«Para mí, asegura Rosales, María Zambrano no sólo es una gran escritora en el terreno del ensayo, sino también, tocándome muy de cerca, en la palabra poética que reside en su escritura. La conocí hace muchos años, en el ámbito universitario, cuando Ortega confiaba en ella más que en nadie» ${ }^{72}$.

«Mi padre se jubiló con el número uno, y con un sueldo de dos mil pesetas. A su muerte, no dejó un céntimo, sólo. ¡SU OBRA!, y los derechos de autor».

\section{José Ortega Spottorno.}

«Para muchos españoles de mi edad, Ortega ha sido una aventura, la aventura de nuestra sensibilidad y nuestra inteligencia. La nunca saciada ambición intelectual y estética, la ávida abertura a los llamamientos espirituales más sugestivos y profundos en que nuestra mente se formaba, la intima exigencia de actualidad y calidad en el pensamiento y en la expresión».

Pedro Laín, rector, que fue, de la Universidad de Madrid y actual presidente de la Real Academia de la lengua.

«...Lo curioso es que después de tantísimos años y diversidad de acontecimientos, el recuerdo de Ortega esté tan fresco en mí... pues olvidando su ausencia, reaccionó como si estuviera vivo y dispuesto a seguir con la discusión».

Victoria Ocampo, en Revista de Occidente, 1963.

Gregorio NATAL ÁlvAREZ
Instituto Mérida
Astorga 1981

Antonio NATAl Álvarez Instituto ISABEL LA CATÓLICA Madrid 1981

72. Los testimonios de Cela, Valente y Rosales, están tomados de la página-homenaje que «El País» dedicó a María Zambrano, el 27 de junio de 1981. 